\title{
Analysis Community's Coping Strategies and Local Risk Governance Framework in Relation to Landslide
}

\author{
Heru Setiawan, Nanette C. Kingma, C.J. van Westen
}

Received: 2905 2014 / Accepted: 09062014 / Published online : 31122014

(c) 2014 Faculty of Geography UGM and The Indonesian Geographers Association

\begin{abstract}
Analysis of people perception and analysis of the coping strategy to landslides are the two elements that are essential to determine the level of preparedness of communities to landslides. To know the preparedness of government and other stakeholders in facing landslide, the analysis risk governance framework was required. A survey using questionnaires with random sampling was applied to assess the level of people perception and people coping strategy related to landslide. Analysis of risk governance frame work was done at the district and sub-district level. The study found that people perception related with landslide dominated by high and moderate level. Age and education are two factors that influence the people's perception to landslide. Local people applied four types coping strategy, which are: economic, structural, social and cultural coping strategy. Totally, 51.6\% respondents have high level, 33.3\% have moderate level and only $15.1 \%$ respondents that have low level of coping strategy. The factors that influence the level of coping strategy are education, income and building type. Analysis of risk governance framework is limited to the three components including stakeholder involvement, risk management and risk communication. Based on the data analysis, the level of stakeholder involvement at the district scope was categorized on the moderate till high and the level of stakeholder involvement at sub-district level was categorized on the high level. Generally, the risk management of Karanganyar was categorized on the moderate level and high level and the risk management in Tawangmangu was categorized on the moderate level. There are some elements must be improved on the risk governance framework, those are data management, the pattern of relationships among stakeholders, increased participation of NGOs, constructed and updated landslide risk map, enhancement of microfinance role in helping the community when disaster strikes and dissemination of information about the landslide to the local community.
\end{abstract}

Keywords: Landslide perception, coping strategies, risk governance framework

\begin{abstract}
Abstrak Analisis persepsi masyarakat dan analisis strategi mengatasi longsor adalah dua elemen yang penting untuk menentukan tingkat kesiapan masyarakat terhadap longsor. Untuk mengetahui kesiapan pemerintah dan pemangku kepentingan lainnya dalam menghadapi longsor, diperlukan untuk analisis kerangka tata kelola risiko bencana. Metode survei menggunakan kuesioner dengan random sampling diterapkan untuk menilai tingkat persepsi masyarakat dan strategi penanggulangan yang berkaitan dengan bencana longsor. Analisis kerangka tata kelola risiko dilakukan di tingkat kabupaten dan kecamatan. Studi ini menemukan bahwa persepsi masyarakat terkait dengan longsor didominasi tingkat tinggi dan sedang. Usia dan pendidikan adalah dua faktor yang mempengaruhi persepsi masyarakat terhadap longsor. Masyarakat setempat dikelompokan menjadi empat jenis strategi penanggulangan, yaitu: ekonomi, struktural, sosial dan budaya strategi bertahan. Sebanyak 51,6\% responden memiliki tingkat tinggi, 33,3\% memiliki tingkat yang moderat dan hanya 15,1\% responden yang memiliki tingkat rendah dalam strategi penanggulangan bencana. Faktor-faktor yang mempengaruhi adalah pendidikan, pendapatan dan jenis bangunan. Analisis kerangka tata kelola risiko terbatas pada tiga komponen, termasuk keterlibatan pemangku kebijakan, manajemen risiko dan komunikasi risiko. Berdasarkan analisis data, keterlibatan pemangku kepentingan di lingkup kabupaten dikategorikan tingkat pada moderat sampai tinggi dan tingkat keterlibatan pemangku kepentingan di tingkat kecamatan dikategorikan pada tingkat tinggi. Secara umum, manajemen risiko di Karanganyar dikategorikan pada tingkat moderat dan tingkat tinggi dan manajemen risiko di Tawangmangu dikategorikan pada tingkat moderat. Ada beberapa elemen harus ditingkatkan pada kerangka tata kelola risiko, yaitu manajemen data, pola hubungan antara para pemangku kepentingan, peningkatan partisipasi LSM, disusun dan diperbaruinya peta resiko longsor, peningkatan peran keuangan mikro dalam membantu masyarakat ketika terjadi bencana, dan penyebaran informasi tentang tanah longsor bagi masyarakat setempat.
\end{abstract}

Kata kunci: persepsi longsor, strategi penanganan, kerangka tata kelola risiko

\section{Introduction}

One of hazards occurred frequently in Indonesia is landslide. Generally, landslides mostly occurred in rural

\section{Heru Setiawan}

Balai Penelitaian Kehutanan Makasar

email: hiero_81@yahoo.com

Nanette C. Kingma, C.J. van Westen

Faculty of Geo-Information Science and Earth Observation, University of Twente areas with hilly topography and close to volcanoes. It is commonly found that the soil condition in this area is fertile with significant amount of water resources and the beautiful panorama to life. Therefore, most of the landslide prone areas have been developed as the villages or cities with high population density. As the results, thousands of people died several thousands of 
houses damages and thousand hectares of land buried due to landslide disasters [Karnawati et al., 2013].

Karanganyar is one of the regency in Indonesia that frequently struck by landslide. Some of the Karangayar's districts are located close to Lawu Volcano which makes the areas susceptible to landslide. Landslides occurred in several sub-districts, for instance Karangpandan, Ngargoyoso, Matesih, Tawangmangu, Jatiyoso, Jumapolo, Jenawi, Kerjo and Jumantono. Two major landslide events were occurred in Tawangmangu Subdistrict on December 27th, in Tengklik Village and Tawangmangu Village. A landslide event in Tengklik Village has resulted in the collapse of 33 houses and a landslide event in Tawangmangu village caused 34 people died. The driving factors of the event were high intensity rainfall, morphological conditions, slopes and land use changes [Prawiradisastra, 2008].

In order to minimize damages, it is necessary to assess and manage areas that are susceptible to landslides. Local people who live in prone areas have coping strategy dealing with landslides and take actions that should be done to minimize the damages. Various local institutions both governmental and non governmental institutions carry out disaster management strategies. Risk governance analysis is one of tools to know the level readiness of stakeholder to cope of hazard in their area. This research focused on local scale both district level and sub-district level and emphasizes on analysis of people perception, analysis of community's coping strategies and analysis of risk governance framework related to landslide in study area.

\section{The Methods}

Analysis risk governance framework was conducted on district scope in Karanganyar District and sub-district scope in Tawangmangu Sub-district. Karanganyar is located between $110^{\circ} 40^{\prime \prime}-110^{\circ} 70^{\prime \prime}$ east longitude and $7^{\circ} 28-7^{\circ} 46^{\prime \prime}$ south latitude. Karanganyar Regency bordered by Sragen Regency at the north, East Java Province at east, Wonogiri and Sukoharjo Regency at the south and Surakarta and Boyolali Regency at the west [BPS, 2011]. Karanganyar District is one of the districts in Central Java Province that have a high susceptibility to disaster. Base on the record data that published by Regional Disaster Mitigation Agency [2012], during 2011 recorded 34 landslide events, 15 windstorms events, 3 flood events and 29 events of fire disasters.

Tawangmangu Sub-district is located close to Lawu Volcano that has highest altitude 3,265 meters above sea level. Most of the areas (65\%) are located on a steep relief with a slope more than $35 \%$. The study area mainly consists of soil depth of more than 90 $\mathrm{cm}$ and dominated by sandy soil that makes this area susceptible to landslide [Wati et al., 2010]. Settlement and agricultural land use are the most rapid developed land use in study area. Based on modified data from Wati et al. [2010] which was collected from the village office, sub-district office and field survey showed the landslides events in Tawangmangu from 2005 till 2010 as many as 42 times that spread in all villages in Tawangmangu Sub-district.

Primary data including community perception and coping strategies was taken in Tengklik Village and Tawangmangu Village. The area of Tawangmangu Village is $337,39 \mathrm{Ha}$ consist of $6.84 \mathrm{Ha}$ paddy field, 177, 24 dry land and the rest 153,30 Ha for others purposes. There are five sub-villages in Tawangmangu, consist of Tawangmangu, Nano, Beji, Nglurah, and Ngledoksari and divided to 12 Rukun Warga and 51 Rukun Tetangga (BPS, 2012). The wide area of Tengklik is $810.78 \mathrm{Ha}$; consist of $45.51 \mathrm{Ha}$ paddy field; 248. 50 dry land and the rest $516.77 \mathrm{Ha}$ for others purposes. Tengklik Village consists of 4 sub-villages; there are Plalar, Guyon, Sodong and Selere, 12 RW and 36 RT. The number of people in Tengklik Village is 3,716 people consist of female 1,864 people and male 1,852 people [BPS, 2012]. This research applied a case study approach that took place at four sub-villages in Tengklik Village consisting of Plalar Sub-village, Guyon Sub-village, Sodong Subvillage and Salere Sub-village and one sub-village in Tawangmangu village namely Ngledoksari Sub-village. Type of research is survey method with the household as the unit of analysis. Random sampling technique was applied to take sample of respondents from the population. By sampling method, the characteristic of population will be known. The information collected from the respondents was analyzed using statistical method. Analysis risk governance framework was conducted to determine the level of stakeholder involvement, disaster management systems and communication patterns among stakeholders in disaster management activities. Analysis of risk governance framework was done at district and sub district scope.

Primary data is data collected and observed directly in the field. The primary data in this study include: (1) Questionnaire data and interviews with head offices were conducted to 24 agencies in Karanganyar and six agencies in Tawangmangu, (2) Questionnaire data and interviews conducted on the population by 93 respondents to obtain data about perception, coping strategy and the people acceptation to landslide risk reduction programs by the government and other stakeholders. The questions included close question with "agree" until "not agree" and open question to give opportunity for respondent to explore their opinion. The answer scored using Linkert scale as 5 if "fully agree" until 1 if "fully not agree", (3) Small group discussion with the head of sub-village to determinate sub-villages boundary and historical landslide data includes location of landslide, damage / casualties caused by landslides and the magnitude of the landslide. Data processing was done after the data collection in the field is completed. Some of the activities carried out at this stage are: (1) Data tabulation, (2) Data scoring (Table 1), and (3) Data digitizing. 
The data analysis process included several techniques, as follow: (1) Descriptive statistics analysis was used to analyze characteristic of respondents including age, income, household size, gender, marital status, education, occupation, building type and landslide, (2) Linear regression analysis was applied to know the factors influencing landslide risk perception, people coping strategy and people acceptation, (3) Cross-tabulation analysis also known as contingency table analysis, is most often used to know the level of respondent's perception, people coping strategy and people acceptation in each village (Plalar, Sodong, Guyon, Salere and Ngledoksari), (4) The chi-square statistic was used to determine the difference of the level of dependent variables (people perception, people coping strategy and people acceptation) within five sub-villages (Guyon, Plalar, Salere, Sodong and
Ngledoksari).

The respondents were distributed proportionally by considering the number of household in each subvillage. According to Sugiyono [2007], the amount of respondent can be determined using formula:

$S=\frac{N \cdot P \cdot Q \cdot \lambda^{2}}{d^{2}(N-1)+P \cdot Q \cdot \lambda^{2}}$

Where:

$\lambda 2=$ Error standard $=1$

$d=$ Standard deviation $=0.05$

$P=Q=$ Probability $=0.5$

$S=$ Total sample

$N=$ Population

Based on the Sugiyono's formulation, the number of sample for every village can be seen on the Table 2 .

Table 1. Scoring to the Variable of Characteristic of Respondents

\begin{tabular}{|c|c|c|c|}
\hline No & Criteria & Score & Type of data \\
\hline 1. & Age (year) & $\begin{array}{l}20-29 \text { is } 1 ; 30-39 \text { is } 2 ; 40-49 \text { is } 3 ; 50-59 \text { is } 4 ;>60 \\
\text { is } 5\end{array}$ & Ordinal \\
\hline 2. & Gender & Male is 1 ; Female is 2 & Nominal \\
\hline 3. & Education & $\begin{array}{l}\text { Elementary school or under is } 1 \text {; Junior high school is } 2 \text {; } \\
\text { Senior High School is } 3 \text {; University is } 4\end{array}$ & Ordinal \\
\hline 4. & Occupation & $\begin{array}{l}\text { Farmer is } 1 \text {; Trader is } 2 \text {; Civil servant is } 3 \text {; Private sector } \\
\text { is } 4 \text {; Others is } 5\end{array}$ & Nominal \\
\hline 5. & Income per-month & $\begin{array}{l}\text { Under minimum regional wage is } 1 \text {; up to minimum } \\
\text { regional wage is } 2\end{array}$ & Ordinal \\
\hline 6. & Building type & Permanent is 1 ; Semi permanent is 2 ; Not permanent is 3 & Nominal \\
\hline 7. & Landslide experience & Never is 1 ; Once is 2 ; Twice is 3 ; More than twice is 3 & Ordinal \\
\hline 8. & Household size & $1-2$ is $1 ; 3-4$ is $2 ; 5-6$ is $3 ;>6$ is 4 & Ordinal \\
\hline 9. & Level of perception & Low is 1 ; Moderate is 2 ; High is 3 & Ordinal \\
\hline 10. & Level of coping strategy & Low is 1 ; Moderate is 2 ; High is 4 & Ordinal \\
\hline 11. & Level of people acceptation & Low is 1 ; Moderate is 2 ; High is 5 & Ordinal \\
\hline
\end{tabular}

Table 2. Sampling Unit Determination

\begin{tabular}{lllccc}
\hline No & Village & Sub-village & $\begin{array}{c}\text { Number of } \\
\text { Household } \\
(\%)\end{array}$ & Percentage & $\begin{array}{c}\text { Number of } \\
\text { Samples }\end{array}$ \\
\hline 1. & Tawangmangu & Ngledoksari & 235 & 17 & $(17 / 100)^{\star} 93=16$ \\
2. Tengklik & Plalar & 210 & 15 & $(15 / 100)^{\star} 93=14$ \\
& & Guyon & 249 & 18 & $(18 / 100)^{\star} 93=16$ \\
& & Sodong & 378 & 27 & $(27 / 100)^{\star} 93=25$ \\
& Selere & 339 & 24 & $(24 / 100)^{\star} 93=22$ \\
& & & & 93 \\
\hline
\end{tabular}


According to Heryanti [2010], risk perception has been influenced by two groups of variables: situational factors and cognitive factors. Situational factors were measured using analysis of characteristic of respondent and cognitive factors were measured using analysis of people knowledge related to landslide. Characteristic of respondents comprises; age, gender, education, household size, occupation, income, building type and the experience of the landslide. Totally, the amount of samples that must be taken are 93 respondents, consists of $69 \%$ were men and $31 \%$ were women. The age of respondents is ranging from 23 to 82 years old, $41 \%$ respondents were between 23 and 39 years old, $45 \%$ were 40 to 59 years old and $13 \%$ were 61 years old or older. Based on the monthly income, $48 \%$ of the respondents reported monthly incomes were lower than Rp 846,000.00 and 52\% more than Rp 846,000.00. As regards level of education, 55\% of respondents had attended elementary school or below, 23\% junior high school, $17 \%$ senior high school and $5 \%$ had a university degree. Regarding the occupation types, at the time of data collection $46 \%$ of the sample were farmer, while $11 \%$ were trader and self-employed, $4 \%$ were civil servant, $20 \%$ were private employees and $18 \%$ have non-permanent occupation. The size of the surveyed households was dominated by the household with the 3 to 4 of family member (58\%), followed by 5 to 6 member with $24 \%$ of respondents, $14 \%$ with 1-2 member and $4 \%$ with more than 6 member. Most of respondents have permanent building (70\%), 17\% semi permanent and $13 \%$ of respondent have non-permanent house.
Regarding on the landslide experience, the majority of respondents (50\%) experienced the landslide more than twice, while $24 \%$ respondents were twice and $26 \%$ respondent have once experienced in landslide

White [1973] defines perception as process by which individuals organize exterior stimuli in order to form some concept of an event or situation. According to Westen and Kingma [2011] the level of risk perception depend on their personal situation, cultural and religious background, social background, economic level, political background, level of awareness, media exposure, other risks and risk reduction situation. People perception about risk plays an important role to know how the people anticipate the negative impact of landslides occurrences. By knowing the people perception the responses of local people to survive and to cope from landslides in the future can be identified.

Perceptions regarding the definition of landslides, most respondents $(40 \%)$ answered that mass of rock and soil were the main fallout, while the location of the landslide occurred dominated in steep slopes area with $68 \%$ respondents. Type landslides that have occurred in the study area were "topple" with (47\%). Perception population regarding the major physical losses caused by landslides is house damage (71\%), while the nonphysical losses are mainly trauma (66\%). Based on the Table 3, it can be seen that the level of people perception related with landslide dominated in high and moderate level.

Totally, $46.2 \%$ respondents have moderate level of risk perception, $47.3 \%$ have high level and only $6.5 \%$

Table 3. Cross Tabulation Between People Perception and Sub-village

\begin{tabular}{|c|c|c|c|c|c|c|c|}
\hline \multicolumn{8}{|l|}{ Count } \\
\hline & & \multicolumn{5}{|c|}{ Sub_village } & \multirow[t]{2}{*}{ Total } \\
\hline & & Guyon & Plalar & Salere & Sodong & Ngledoksari & \\
\hline \multirow[t]{3}{*}{ People_perception } & Low & 0 & 1 & 3 & 1 & 1 & 6 \\
\hline & Moderate & 11 & 6 & 11 & 6 & 9 & 43 \\
\hline & High & 5 & 7 & 8 & 18 & 6 & 44 \\
\hline \multicolumn{2}{|c|}{ Total } & 16 & 14 & 22 & 25 & 16 & 93 \\
\hline
\end{tabular}

Table 4. Chi-square Tests of People Perception

\begin{tabular}{lccr}
\hline \multicolumn{4}{c}{ Chi-Square Tests } \\
\hline Value & df & Asymp. Sig. (2-sided) & .115 \\
\hline Pearson Chi-Square & $12.911 \mathrm{a}$ & 8 & .092 \\
Likelihood Ratio & 13.616 & 8 & .409 \\
Linear-by-Linear Association & .682 & 1 & \\
N of Valid Cases & 93 & & \\
a. 5 cells (33.3\%) have expected count less than 5. The minimum expected count is .90.
\end{tabular}


respondents that have low level of perception. On the high level of perception, the highest percentage is $72 \%$ respondents in Sodong Sub-village. The highest percentage of the moderate level of perception in Guyon Sub-village with $68.8 \%$ respondents and on the low level of perception, the highest percentage is $13.6 \%$ respondents in Salere Sub-village. Spatial distribution of the level of respondent's perception to landslide was displayed on the Appendix 1.

Chi-square test is used to determine the difference of people perception related to landslide within five sub-villages (Guyon, Plalar, Salere, Sodong and Ngledoksari. The null hypothesis ( $\mathrm{H} 0)$ stated that there is no difference of people perception in five sub-villages. The result from the test as mentioned on the Table 4.

The decision making was determined by looking at the value of significance probability (P-value). Null hypothesis is accepted if the P-value $>0.05$, and null hypothesis is rejected if $\mathrm{P}$-value $<0.05$. From Table 3 , it can be seen that the value of Asymp. Sig. (2-sided) is 0.115 or more than $0.05(0.115>0.05)$, the decision is
$\mathrm{H} 0$ is accepted, meaning that there was no differences of people perception related to landslide within five sub-villages.

The multiple linear regression analysis was used to determine the factors that influence the level of people perception related to landslide. Correlations test as a part of regression analysis output was conducted to determine the factors associated with level of people perception. The results of correlation analysis are presented in the Table 5.

The null hypothesis used in this analysis is independent variables (age, gender, education, occupation, income, household size, building type and landslide experience) do not have a correlation with the dependent variable (people perception). Decisionmaking is based on the null hypothesis that will be accepted if the value of Sig. (1-tailed) $>0.05$. From calculations process using SPSS software can be seen that there are five variables that have a sig. (1-tailed) $<0.05$, those are age, education, occupation, income, household size and building type. It can be concluded

Table 5. Correlation Analysis of People Perception

\begin{tabular}{ll}
\hline Correlations & \\
\hline Independent variable & Sig. (1-tailed) \\
Age & $.000^{*}$ \\
Gender & .080 \\
Education & $.000^{*}$ \\
Occupation & $.003^{*}$ \\
Income & $.000^{\star}$ \\
household size & $.048^{\star}$ \\
Building_type & $.000^{*}$ \\
Landslide_exp & .235 \\
\hline
\end{tabular}

Table 6. Coefficients of People Perception

\begin{tabular}{|c|c|c|c|c|c|}
\hline \multicolumn{6}{|l|}{ Coefficientsa } \\
\hline \multirow[t]{2}{*}{ Model } & \multicolumn{2}{|c|}{ Unstandardized Coefficients } & \multirow{2}{*}{$\begin{array}{r}\begin{array}{r}\text { Standardized } \\
\text { Coefficients }\end{array} \\
\text { Beta }\end{array}$} & \multirow[t]{2}{*}{$\mathrm{t}$} & \multirow[t]{2}{*}{ Sig. } \\
\hline & $\mathrm{B}$ & Std. Error & & & \\
\hline (Constant) & 2.314 & .359 & & 6.443 & .000 \\
\hline Age & -.178 & .044 & -.346 & -4.074 & $.000^{*}$ \\
\hline Gender & -.097 & .107 & -.074 & -.912 & .364 \\
\hline Education & .313 & .061 & .478 & 5.128 & $.000^{*}$ \\
\hline Occupation & .001 & .029 & .003 & .034 & .973 \\
\hline Income & .175 & .103 & .143 & 1.688 & .095 \\
\hline Household_size & .007 & .059 & .008 & .112 & .911 \\
\hline Building_type & .030 & .086 & .035 & .348 & .729 \\
\hline Landslide_exp & -.034 & .053 & -.047 & -.655 & .514 \\
\hline
\end{tabular}

a. Dependent Variable: People_perception 
Table 7. Cross Tabulation Between Level of Coping Strategy and Sub-village

\begin{tabular}{llcccccc}
\hline \multicolumn{7}{c}{ Coping_strategy * Sub_village Crosstabulation } \\
\hline Count & & \multicolumn{7}{c}{ Sub_village } & Total \\
\cline { 2 - 7 } & & Guyon & Plalar & Salere & Sodong & Ngledoksari & \\
\hline Coping_strategy & Low & 1 & 4 & 4 & 5 & 0 & 14 \\
& Moderate & 9 & 7 & 7 & 5 & 3 & 31 \\
& High & 6 & 3 & 11 & 15 & 13 & 48 \\
\multicolumn{1}{c}{ Total } & 16 & 14 & 22 & 25 & 16 & 93 \\
\hline
\end{tabular}

Table 8. Chi-square Tests of People Coping Strategy

\begin{tabular}{lccc}
\hline & Chi-square Tests & & \\
\hline & Value & df & Asymp. Sig. (2-sided) \\
\hline Pearson Chi-Square & $17.701^{\text {a }}$ & 8 & $.024^{\star}$ \\
Likelihood Ratio & 20.112 & 8 & .010 \\
Linear-by-Linear Association & 5.914 & 1 & .015 \\
N of Valid Cases & 93 & & \\
\hline
\end{tabular}

a. 6 cells (40.0\%) have expected count less than 5. The minimum expected count is 2.11 .

that the variables that have a correlation with the local people perception are age, education, occupation, income, household size and building type. Table 6 is the result of coefficients test. Coefficients test as a part or linear regression analysis output was conducted to determine the influence of one by one independent variable with the dependence factor.

The null hypothesis stated that partially the independent variables not have significant influence with the level of people perception. A method for decision-making is done using a probability value (P-value) 0.05 . If the significance value $>0.05$, null hypothesis is accepted. Base on the Table 6, can be seen there are only two variables that have significant influence to the people perception, that are age and education. Findings from this study indicated that two predictor variables, age and education, have a significant influence with the variation of local people perception to landslide.

Coping strategies refer to the application of indigenous knowledge in the face of hazards such as landslides Twigg (2004). People who live in susceptible areas have specified strategy to deal with disaster and to adapt with environment around it. An analysis of the level of coping strategy for communities in disasterprone areas is essential to reduce the negative impact caused by the disaster. Coping Strategy that be conducted by local people related with landslide can be performed in the scope of household and community. Economic coping strategy undertaken by household focused on increasing income. Structural coping strategy focused on strengthening building, social coping strategies focused on participate on social gathering activities such as "pengajian" and "arisan". Coping strategy conducted by communities consisted of economic coping strategy that focused on strengthening "koperasi" institutions and "arisan", structural / technological coping strategy is focused on the improvement of public facility such as roads and water channel. Social coping strategy focused on night patrol activities, "pengajian" and meetings in order to assist people who affected by landslides.

Totally, 51.6\% respondents have high level, 33.3\% have moderate level and only $15.1 \%$ respondents that have low level of coping strategy. At high levels of coping strategy (Table 7), the highest percentage is Ngledoksari Sub-village with $81.3 \%$. At moderate levels, Guyon Subvillage is the highest percentage with $56.3 \%$ respondents and at a low level, dominated by respondent in Plalar Sub-village with $28.6 \%$ respondents. Spatial distribution of the level of respondent's coping strategy to landslide was displayed on the Appendix 2. The chi-square test is used to determine the difference of people coping strategy related to landslide within five sub-villages (Guyon, Plalar, Salere, Sodong and Ngledoksari). Null hypothesis stated there is no difference of people coping strategy in five sub-villages.

Based on the value of significance probability (P-value), can be seen that the value of Asymp. Sig. (2-sided) is 0.024 or less than $0.05(0.024<0.05)$, meaning that there was a difference level of people coping strategy in five sub-villages (Table 8).

There are several factors that pre-assumed have a correlation with the level of coping strategy comprise age, gender, education, occupation, income, household size, building type and landslide experience. The results of correlation analysis are presented in Table 9. 
Table 9. Correlation Analysis of People Coping Strategy

\begin{tabular}{ll}
\hline \multicolumn{2}{c}{ Correlations } \\
\hline Independent variable & Sig. (1-tailed) \\
Age & $.000^{\star}$ \\
Gender & $.000^{\star}$ \\
Education & $.000^{\star}$ \\
Occupation & .389 \\
Income & $.000^{\star}$ \\
household size & .063 \\
Building_type & $.000^{\star}$ \\
Landslide_exp & $.027^{\star}$ \\
\hline
\end{tabular}

The null hypothesis stated that independent variables do not have a correlation with the dependent variable. Decision-making is based on the null hypothesis that will be accepted if the value of Sig. $(1$-tailed $)>0.05$. From calculations process using SPSS software can be seen that there are six variables that have a sig. (1-tailed) $<0.05$, which are age, gender, education, income, building type and landslide experiences. It can be concluded that the variables that have a correlation with the people coping strategy are age, gender, education, income, building type and landslide experiences. Table 10 is the result of coefficients test that was conducted to determine the influence of one by one independent variable with the dependence factor.

The null hypothesis stated that partially the independent variables not have significant influence with the level of people coping strategy (dependent variables). The decision-making is done using a probability value (P-value) 0.05 . If the significance value $>0.05$, null hypothesis is accepted. Base on the Table 5.12 can be seen there are only three variables that have significant influence to the level of people coping strategy, that are education, income and building type.

Governments together with other stakeholders undertake a wide range of programs to prevent the occurrence of landslides and to minimize the negative impact because of landslide. The types of coping strategy conducted by the government and NGOs sometimes are not match with local people expectations. So, it is necessary to analyze the public acceptation of coping

Table 10. Coefficients of People Coping Strategy

\begin{tabular}{lccccc}
\hline \multicolumn{1}{c}{ Model } & \multicolumn{2}{c}{ Unstandardized Coefficients } & $\begin{array}{c}\text { Standardized } \\
\text { Coefficients }\end{array}$ & $\mathrm{t}$ & Sig. \\
\hline (Constant) & $\mathrm{B}$ & Std. Error & Beta & & .000 \\
Age & 2.625 & .368 & & 7.140 & .920 \\
Gender & .004 & .045 & .007 & .100 & .382 \\
Education & -.096 & .109 & -.061 & -.879 & $.003^{*}$ \\
Occupation & .195 & .063 & .248 & 3.116 & .289 \\
Income & -.032 & .030 & -.071 & -1.067 & $.001^{*}$ \\
Household_size & .366 & .106 & .250 & 3.455 & .430 \\
Building_type & .047 & .060 & .047 & .793 & $.000^{*}$ \\
Landslide_exp & -.511 & .088 & -.497 & -5.823 & .071 \\
a. Dependent Variable: Coping_strategy & .054 & -.113 & -1.829 & \\
\hline
\end{tabular}

Table 11. Cross Tabulation the Level of People Acceptation and Sub-village

\begin{tabular}{llcccccc}
\hline \multicolumn{7}{c}{ Count } & \multicolumn{7}{c}{ People_acceptation * Sub_village Crosstabulation } & Total \\
\cline { 2 - 7 } & Guyon & Plalar & Salere & Sodong & Ngledoksari & \\
\hline People_ & Low & 9 & 7 & 7 & 7 & 1 & 31 \\
acceptation & Moderate & 6 & 5 & 10 & 13 & 1 & 35 \\
& High & 1 & 2 & 5 & 5 & 14 & 27 \\
Total & 16 & 14 & 22 & 25 & 16 & 93 \\
\hline
\end{tabular}


Table 12. Chi-square Test of People Acceptation

\begin{tabular}{lccr}
\hline & Chi-Square Tests & & \\
& Value & df & Asymp. Sig. (2-sided) \\
\hline Pearson Chi-Square & $37.119 \mathrm{a}$ & 8 & $.000^{*}$ \\
Likelihood Ratio & 35.487 & 8 & .000 \\
Linear-by-Linear Association & 19.854 & 1 & .000 \\
N of Valid Cases & 93 & & \\
\hline
\end{tabular}

a. 4 cells $(26.7 \%)$ have expected count less than 5 . The minimum expected count is 4.06 .

strategy conducted by the government and other stakeholders. The level of public acceptation to the landslide risk reduction programs shown in the Table 11.

Spatial distribution of the level of respondent's acceptation to landslide risk reduction program was displayed on the Appendix 3. Chi-square test is used to determine the difference of people acceptation related to landslide risk reduction programs within five sub-villages (Guyon, Plalar, Salere, Sodong and Ngledoksari). Chi-square test used the null hypothesis (H0) which stated that there is no difference level of people acceptation in five sub-villages.

The result from the test as mentioned on the Table 12. Base on the value of significance probability (P-value), can be seen that the value of Asymp. Sig. (2-sided) is 0.00 or less than $0.05(0.00<0.05)$ meaning that there was a differences level of people acceptation in five sub-villages. There are several factors that pre-assumed have a correlation with the level of people acceptation comprise age, gender, education, occupation, income, household size, building type and landslide experience. The result from correlation analysis as mentioned in the Table 13

Table 13. Correlation of People Acceptation

\begin{tabular}{rr}
\hline Correlations \\
\hline Age & Sig. (1-tailed) \\
Gender & $.000^{\star}$ \\
Education & .091 \\
Occupation & $.011^{\star}$ \\
Income & .411 \\
Household size & $.017^{\star}$ \\
Building_type & .447 \\
Landslide_exp & .194 \\
\hline
\end{tabular}

The null hypothesis stated that independent variables do not have a correlation with the dependent variable. Decision-making is based on the null hypothesis that will be accepted if the value of Sig. (1-tailed) $>0.05$. From calculations process using SPSS software can be seen that there are four variables that have a sig. (1-tailed) < 0.05, which are age, education, income and landslide experiences. It can be concluded variables that have a correlation with the people acceptation are age, education, income and landslide experiences. Coefficients table is one of output from linear regression analysis which is used to know the influence of one by one independent variable with the dependence variable. The coefficients table as mentioned in the Table 14.

The null hypothesis stated, partially the independents variables not have significant influence with the independent variables. The decision-making is done using a probability value 0.05 . If the significance value $>0.05$, null hypothesis is accepted. Base on the Table 13, can be seen there are only three variables that have significant influence to the people acceptation on landslide risk reduction programs, those are age, gender and landslide experience.

The correlations between perception and coping strategy people were known by statistical calculation using correlation analysis see Table 15 .

Based on the Table 15 can be explained that the correlation coefficient between perception and people coping strategy is 0.535 . Correlation coefficient is higher than 0.5 indicates that the correlation between perception and coping strategy is strong. A positive correlation coefficient shows the correlation between people perception and coping strategy is directly proportional means that the raise of the perception will follow the increasing of the coping strategy.

Null hypothesis (H0) states that there is no correlation between people perceptions and people coping strategy. Analysis using the value of significance probability (P-value) states that $\mathrm{H} 0$ is accepted if the probability $>0.05$, and $\mathrm{H} 0$ is rejected if probability < 0.05 . From Table 6.21 , it can be seen that the value of Asymp. Sig. (2-sided) is 0.000 or less than 0.05 (0.000 $<0.05)$, the decision is $\mathrm{H} 0$ is rejected, meaning that there was significant correlation between perception people and people coping strategy.

From Table 16, it can be seen that the correlation coefficient between perception and people acceptation is -0.255 . Correlation coefficient is close to null shows that the correlation between people perception and 
Table 14. Coefficients Value of Variables of People Acceptation

\begin{tabular}{|c|c|c|c|c|c|}
\hline \multicolumn{6}{|c|}{ Coefficientsa } \\
\hline \multirow[t]{2}{*}{ Model } & \multicolumn{2}{|c|}{ Unstandardized Coefficients } & \multirow{2}{*}{$\begin{array}{r}\begin{array}{c}\text { Standardized } \\
\text { Coefficients }\end{array} \\
\text { Beta }\end{array}$} & \multirow[t]{2}{*}{$\mathrm{t}$} & \multirow[t]{2}{*}{ Sig } \\
\hline & B & Std. Error & & & \\
\hline (Constant) & 2.915 & .597 & & 4.880 & .000 \\
\hline Age & .227 & .073 & .341 & 3.128 & $.002^{*}$ \\
\hline Gender & -.423 & .178 & -.249 & -2.382 & $.019^{*}$ \\
\hline Education & .021 & .102 & .025 & .209 & .835 \\
\hline Occupation & .085 & .048 & .177 & 1.767 & .081 \\
\hline Income & -.253 & .172 & -.160 & -1.469 & .146 \\
\hline Household_size & .068 & .097 & .062 & .701 & .485 \\
\hline Building_type & .097 & .143 & .087 & .677 & .500 \\
\hline Landslide_exp & -.382 & .087 & -.406 & -4.371 & $.000^{*}$ \\
\hline
\end{tabular}

a. Dependent Variable: People_acceptation

Table 15. Correlation Between People Perception and Coping Strategy

\begin{tabular}{llrr}
\hline \multicolumn{3}{c}{ Correlations } \\
\hline \multicolumn{1}{c}{ People_perception } & Coping_strategy \\
\hline People_perception & Pearson Correlation & 1 & $.535^{* *}$ \\
& Sig. (2-tailed) & .000 \\
& $\mathrm{~N}$ & 93 & 93 \\
Coping_strategy & Pearson Correlation & $.535^{* *}$ & 1 \\
& Sig. (2-tailed) & .000 & 93 \\
& $\mathrm{~N}$ & 93 & \\
${ }^{* *}$. Correlation is significant at the 0.01 level (2-tailed). & & \\
\hline
\end{tabular}

people acceptation are weak. Negative values of correlation coefficient indicate the correlation between people perception and people acceptation is inversely proportional, means that the raise of the people perception will follow the declining of the people acceptation.

Analysis using the value of significance probability (P-value) stated that the the value of Asymp. Sig. (2-sided) is 0.014 or less than $0.05(0.014<0.05)$, meaning that there was a significant correlation between people perception and people acceptation. The two methods of decision-making produced the same conclusion that there was a significant correlation between people perception and people acceptation. From the Table 6.23, it can be seen that correlation coefficient between people coping strategy and people acceptation is -0.085 . The value of correlation coefficient is close to null shows that the correlation between people coping strategy and people acceptation is very weak. Negative correlation coefficient values indicate the relationship between people coping strategy and people acceptation is inversely proportional, means that the raise of the people coping strategy will follow the declining of the people acceptation.

Analysis using the value of significance probability (P-value) stated that the value of Asymp. Sig. (2-sided) is 0.419 or greater than $0.05(0.419>0.05)$, meaning that there was no correlation between people coping strategy and people acceptation. Finally, the two methods of decision-making produced the same conclusion that there was no correlation between people coping strategy and people acceptation (Table 17).

\section{Result and Discussion}

Governance is the processes and institutions, both formal and informal, that guide and restrain the collective activities of a group (Nye and donahue, 2000 cited from lomagin, 2010). According to the IRGC (2011), risk governance framework consists of five basic components include a pre-assessment, risk management, risk appraisal, tolerability and acceptability judgment and risk communication. In tis research, analysis of 
Table 16. Correlation Between People Perception and People Acceptation

\begin{tabular}{|c|c|c|c|}
\hline \multicolumn{4}{|c|}{ Correlations } \\
\hline & & People_perception & People_acceptation \\
\hline \multirow[t]{3}{*}{ People_perception } & Pearson Correlation & 1 & $-.255^{\star}$ \\
\hline & Sig. (2-tailed) & & .014 \\
\hline & $\mathrm{N}$ & 93 & 93 \\
\hline \multirow[t]{3}{*}{ People_acceptation } & Pearson Correlation & $-.255^{\star}$ & 1 \\
\hline & Sig. (2-tailed) & .014 & \\
\hline & $\mathrm{N}$ & 93 & 93 \\
\hline
\end{tabular}

*. Correlation is significant at the 0.05 level (2-tailed).

Table 17. Correlation Between People Perception and People Acceptation

\begin{tabular}{llrr}
\hline & \multicolumn{2}{c}{ Correlations } & \\
\hline \multirow{2}{*}{ People_acceptation } & People_acceptation & Coping_strategy \\
& Pearson Correlation & 1 & -.085 \\
& Sig. (2-tailed) & & .419 \\
& $\mathrm{~N}$ & 93 & 93 \\
Coping_strategy & Pearson Correlation & -.085 & 1 \\
& Sig. (2-tailed) & .419 & \\
& $\mathrm{~N}$ & 93 & 93 \\
\hline
\end{tabular}

risk governance framework is limited to the three components including stakeholder involvement, risk management and risk communication. Analysis of risk governance framework at the district scope and subdistrict scope was done using a questionnaire tools with close-ended question and depth interviews with stakeholders, both government and non government institution.

Based on the data analysis, the level of stakeholder involvement at the district level showed that the level of stakeholder involvement on disaster activities in Karanganyar is moderate till high. Base on the data analysis, $45.8 \%$ of respondents stated that stakeholder involvement in Karanganyar District categorized in the moderate level, $37.5 \%$ respondents stated that the level of stakeholder involvement of the risk governance framework is high and the rest (16.7\%) respondents stated that stakeholder involvement of the risk governance framework is low. On the sub-district scope, $50 \%$ of respondents stated that stakeholder involvement in Tawangmangu Sub-district categorized in the high level, $41.7 \%$ respondents stated that the level of stakeholder involvement of the risk governance framework is moderate and the rest $(8.3 \%)$ respondents stated that the level of stakeholder involvement at subdistrict level is low.

Based on the data analysis was known that $45.8 \%$ of respondents stated that risk management at
Karanganyar categorized into high and moderate and 8.3.5\% respondents stated that the risk management in Karanganyar categorized on the low level. On the sub-district scope, $37.5 \%$ of respondents stated that risk management level in Tawangmangu Sub-district categorized in the high level, 50\% respondents stated that the level of risk management is moderate and the rest $(12.5 \%)$ respondents stated that the level of risk management at sub-district level is low.

Based on the data analysis can be explained that $50 \%$ of respondents stated that risk communication in Karanganyar District categorized as moderate level, $33.3 \%$ respondents have opinion that risk communication among stakeholders categorized into high level and $16.7 \%$ of respondents stated that risk communication among stakeholders was categorized on the low level. On the sub-district scope, 25\% of respondents stated that risk communication level in Tawangmangu Sub-district categorized in the high level, $62.5 \%$ respondents stated that the level of risk management of the risk governance framework is moderate and the rest (12.5\%) respondents stated that the level of risk management at sub-district level is low.

Analysis on the components of risk governance framework that need to be improved shows that on the stakeholder involvement, improvement must be done on the three elements, those are data management, the pattern of relationships among 
stakeholders and increased participation of NGOs in disaster activities. There are two elements that need improvement on the risk management component; those are constructed and updated landslide risk map and enhancement of microfinance role in helping the community when disaster strikes. Improvements to the risk communication component must be done to the dissemination of information about the landslide to the local community.

\section{Conclusion}

The research related to people perception on landslide becomes important because by knowing the people perception about landslide will be known the response of people to survive and to cope from landslide in the future. People's perception of landslides at the research site categorized on the high and moderate levels. Thus, the level of people's knowledge related to landslides can also be categorized in the high and moderate. The level of people's perception of landslides was influenced by two factors, those are education and age. The higher of education level of respondents, the higher of perception level, whereas the older age of respondent, the lower of perception level related to landslides.

There was a positive correlation between people perception and people coping strategy, meaning that the raise of the perception will follow the increasing of the coping strategy. The high level of people perception related to landslides have affected the level of people coping strategy will be high. Coping Strategy that be conducted by local people related with landslide can be performed in the household scope and community scope. On the household scope, coping strategies focusing on increasing income by selling agricultural product, strengthening building, applied soil conservation on agricultural land and participate in pengajian and arisan. On the community scope, coping strategies focusing on strengthening koperasi and arisan, construct public facilities such as roads, water channel, installation of gabion and retaining wall, night patrol activities and held traditional ceremony was called Ruwahan and Suroan. The levels of coping strategy influenced by the level of education, income and building type. The increasing levels of people education will be foollowed by increase of people knowledge to the various types of coping strategies. It will have an impact on the raise of public awareness both individuals and community in applying the various coping strategies to deal with landslides. Income and building type are an indicator of social economic of respondents. The higher the income indicate the higher coping strategies levels. The higher levels of income also affects the type of building. People with high income levels would build permanent houses that made of brick and concrete. The permanent house has a higher strength than semi-permanent or not permanent building. So that, people with permanent building has a lower level of vulnerability than the people who live in the nonpermanent or semi-permanent building.

Society either individually or in groups have done various coping startegy to prevent the occurences of landslides in the future and to minimize negative impacts due to landslides. Beside the local community, government and non-government organizations are also implementing coping strategies to reduce the risk of landslides. Landslide risk reduction program conducted by the government and non-government sometimes does not in line with the wishes and expectations of the people who live in landslide prone areas, so that, it is necessary to analyze of the level of public acceptation to the landslide risk reduction programs undertaken by government and non-government organizations. The government as a main actor and the owner of authority on disaster mitigation conducted various landslide risk reduction programs that carried out before, during and after landslide occurrences. Landslide risk reduction programs conducted by the government and nongovernment organizations have to evaluate in order to avoid overlapping of programs and to minimize miss communication among stakeholders. Analysis of risk governance framework is one of tools that can be used to evaluate the governance of disaster within the district and sub-district scope. In this research, there are three elements of risk governance framework that analyzed including the stakeholder involvement, risk management and risk communication.

The results of analysis is showed that stakeholder involvement at Karanganyar District categorized in the moderate level and at Tawangmangu Sub-district categorized in the high level. Risk management at Karanganyar categorized at the high and moderate level and at Tawangmangu Sub-district categorized in the high level. Risk communication in Karanganyar District categorized as moderate level and at Tawangmangu Sub-district categorized in the high level. There are several components that need to be improved including data management, the pattern of relationships among stakeholders, participation of NGOs in disaster activities, constructed and updated landslide risk map, enhancement of microfinance role in helping the community when disaster strikes and enhancement of dissemination about landslide to the local community.

\section{Acknowledgement}

Thank to Dr. Dyah Rahmawati Hisbaron for valuable comments and his support during the research and thanks to review for the constructive comments. 


\section{References}

BPBD (Regional Disaster Mitigation Agency). (2011), Recapitulation of disasters in Karanganyar District in 2011, Karanganyar, Central Java.

BPS (Centre of Statistic Bureau) of Karanganyar Regency. (2011), Karanganyar in figures 2011 (in bahasa). Centre of Statistic Bureau of Karanganyar Regency.

BPS (Centre of Statistic Bureau) of Karanganyar Regency. (2012). Tawangmangu Sub-District in figures 2012 (in bahasa). Statistic Coordinator of Tawangmangu Sub-district.

Heryati, D.N. (2012), Community based approach to assess flood risk perception and coping mechanism along Code River, Yogyakarta Municipality, M.Sc Thesis. ITC Univ. Twente and GMU Yogyakarta.

IRGC (International Risk Governance Council). (2008), An introduction to The IRGC risk governance framework, Geneva, Switzerland.

Karnawati, D., Fathani, T.F., Wilopo, W., Andaani, B. (2013), Hybrid socio-technical approach for landslide risk reduction in Indonesia, Progress of geodisaster mitigation technology in Asia, Environmental Science and Engineering 2013.

Lomagin. (2010), International energy institution, http://issrb.ru/content/program/Lomagin $\% 20$ 2010\%20\%20International\%20Energy\%20Institutions.pdf. Accessed on 23 December 2012.

Prawiradisastra, S. (2008), Analisis of morphology and geology of landslides in Ledoksari Village, Ka- ranganyar Regency (in bahasa), Jurnal sains dan teknologi Indonesia 10(2): 84-89.

Sugiyono. (2007), Quantitative-qualitative research development (in bahasa), Alfabeta, Bandung

Twigg, J. (2004), Disaster risk reduction: mitigation and preparedness in development and emergency programming: humanitarian practice network, London, United Kingdom.

Westen, V. N.C., \& Kingma. (2011), Guide book session 7: Disaster risk management, Twente University ITC School on Disaster Geo-information Management, Enschede, The Netherlands.

White, G. F. (1973), Natural hazards research, in Environmental risks and hazards, (Ed, S. L. Cutter) Prentice Hall, Englewood Cliffs, New Jersey, pp. 4-17.

Wati, S.E. T., Hastuta. S., Widjojo. F., Pinem. (2010), Landslide susceptibility mapping with heuristic approach in mountainous area; A case study in Tawangmangu Sub-District, Central Java, Indonesia, International archives of the photogrammetry, remote sensing and spatial information science, Volume XXXVIII, Kyoto Japan. 


\section{APPENDICES}

Appendix 1. Spatial Distribution of the Level of Respondent's Perception to Landslide

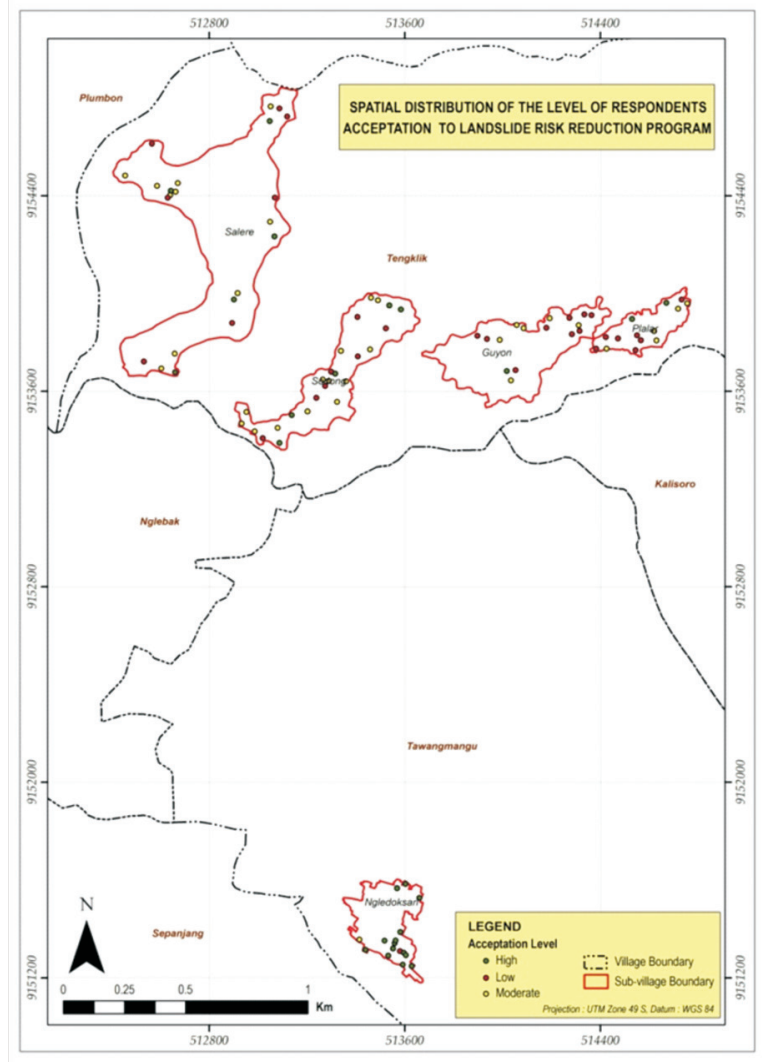

Appendix 2. Spatial Distribution of the Level of Respondent's Coping Srategy to Landslide.

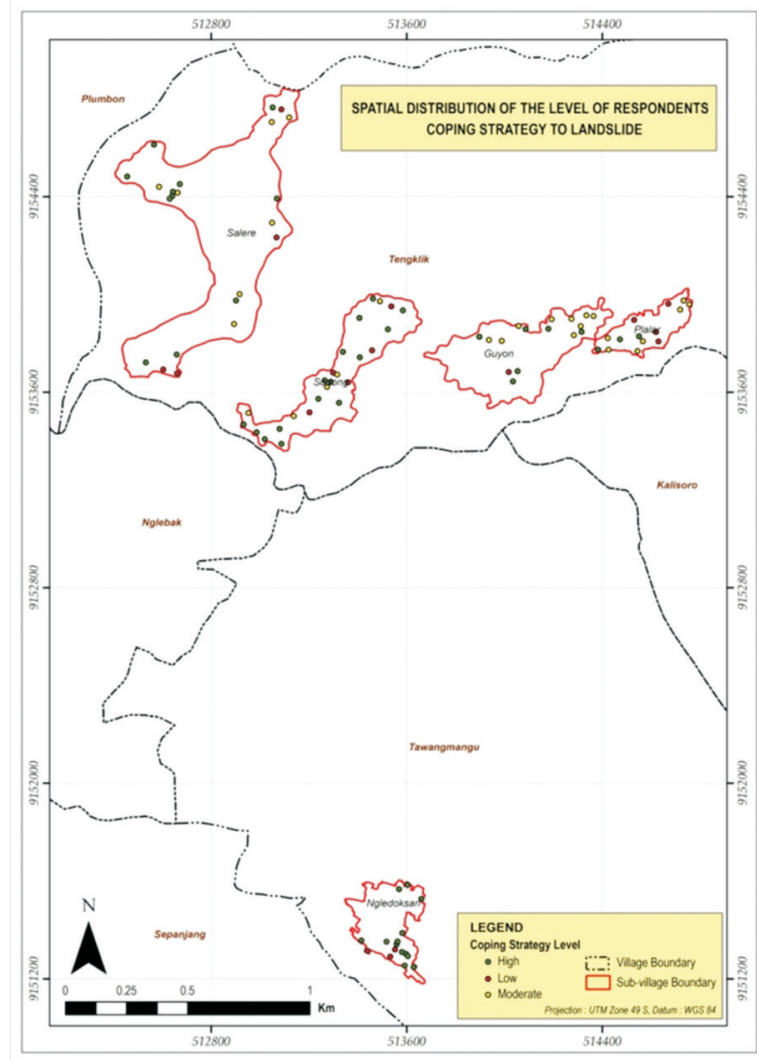

Appendix 3. Spatial Distribution of the Level of Respondent's Acceptation to Landslide Risk Reduction Program.

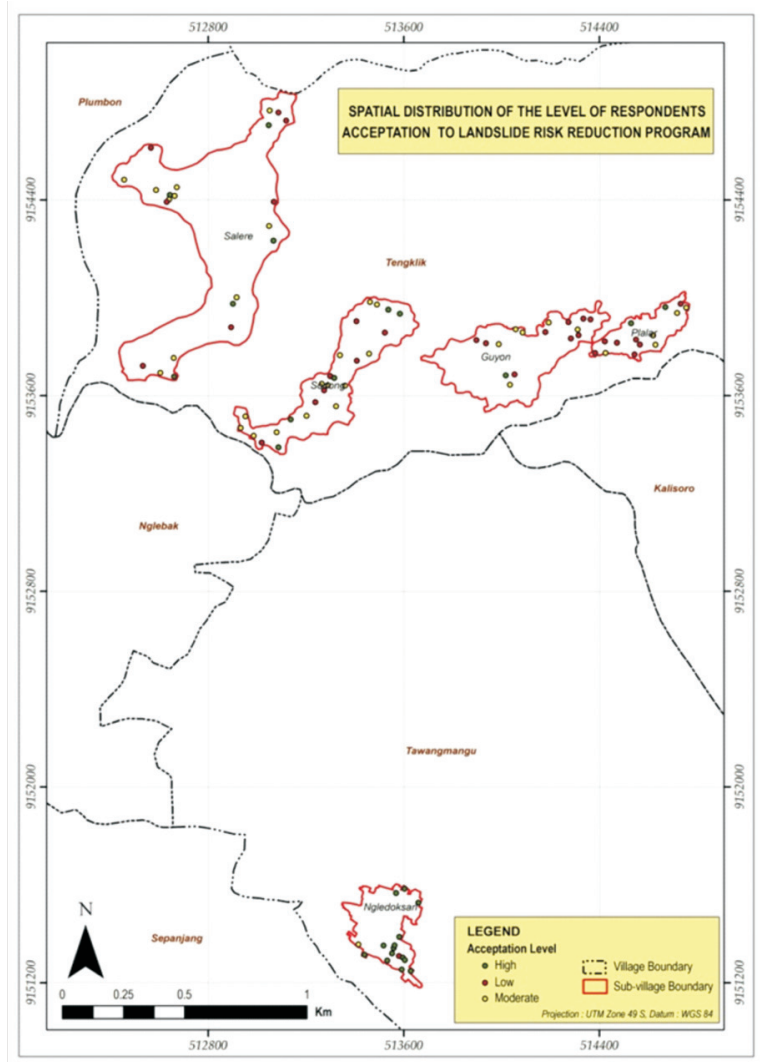

